\title{
ペロブスカイト型酸化物 $\mathrm{La}_{1-x} \mathrm{~A}_{x} \mathrm{MnO}_{3}(\mathrm{~A}=\mathrm{Na}, \mathrm{K}, \mathrm{Rb})$ の 濃アルカリ水溶液中での電気化学的酸素還元特性
}

\author{
林 政彦 ${ }^{\mathrm{a}}$, 兵頭 健生 ${ }^{\mathrm{b}}$, 三浦 則雄 ${ }^{\mathrm{c}}$, 山添 曻*a \\ ${ }^{\mathrm{a}}$ 九州大学大学院総合理工学研究科物質理工学尃攻（T 816-8580 春日市春日公園 6-1) \\ '現在：長崎大学工学部材料工学科（广 852-8521 長崎市文教町 1-14) \\ ‘九州大学先端科学技術共同研究センター（％ 816-8580 春日市春日公園 6-1）
}

\section{Electrochemical Oxygen Reduction Properties of Perovskite-type Oxides $\mathrm{La}_{1-x} \mathrm{~A}_{x} \mathrm{MnO}_{3}(\mathrm{~A}=\mathrm{Na}, \mathrm{K}, \mathbf{R b})$ in Concentrated Alkaline Solution}

\author{
Masahiko HAYASHI, ${ }^{\mathrm{a}}$ Takeo HYODO, ${ }^{\mathrm{b}}$ Norio MIURA, ${ }^{\mathrm{c}}$ and Noboru YAMAZOE*a
}

\begin{abstract}
${ }^{a}$ Department of Molecular and Material Sciences, Graduate School of Engineering Sciences, Kyushu University (6-1 Kasuga-Koen, Kasuga-shi, 816-8580, Japan)

${ }^{b}$ Present address : Department of Materials Science and Engineering, Faculty of Engineering, Nagasaki University (1-14 Bunkyo-machi, Nagasaki-shi, 852-8521, Japan)

${ }^{\mathrm{c}}$ Advanced Science and Technology Center for Cooperative Research, Kyushu University (6-1 Kasuga-Koen, Kasuga-shi, 816-8580, Japan)
\end{abstract}

Received September 3, 1999 ; Accepted November 6, 1999

\begin{abstract}
Oxygen reduction properties of gas diffusion-type oxygen electrodes loaded by 50 wt $\%$ with perovskite-type oxides, $\mathrm{La}_{1-x} \mathrm{~A}_{x} \mathrm{MnO}_{3}(\mathrm{~A}=\mathrm{Na}, \mathrm{K}, \mathrm{Rb}, 0.0 \leqq x \leqq 0.2)$, were investigated in 8 mol dm${ }^{-3} \mathrm{KOH}$ aqueous solution at $60^{\circ} \mathrm{C}$ under air flow. Among these oxides, $\mathrm{La}_{0.8} \mathrm{Rb}_{0.2} \mathrm{MnO}_{3}$ gave the highest electrode performance, $i$. e., current density of $341 \mathrm{~mA} \mathrm{~cm} \mathrm{~m}^{-2}$ at $-150 \mathrm{mV}$ vs. $\mathrm{Hg} / \mathrm{HgO}$. This oxide was found to be highly active for the direct 4-electron reduction of oxygen as revealed by a rotating ring-disk electrode (RRDE) analysis. Electrode performances changed with a change in A or $x$ over the oxides, and tended to be higher with the oxide which exhibited a smaller amount of oxygen desorption in temperature-programmed desorption (TPD) experiments. On the basis of the iodometry and electron spin resonance (ESR) analysis, the 4-electron reduction was suggested to take place most favorably at the sites composed of a pair of $\mathrm{Mn}^{3+}$ and $\mathrm{Mn}^{4+}$ on the oxide surface. The electrode loaded with $\mathrm{La}_{0.8} \mathrm{Rb}_{0.2} \mathrm{MnO}_{3}$ was confirmed to be fairly stable over a continuous operation for $100 \mathrm{~h}$ under a galvanostatic condition of $300 \mathrm{~mA} \mathrm{~cm} \mathrm{~cm}^{-2}$. The same electrode allowed to construct a zinc-air battery with a maximum power density as large as $293 \mathrm{~mW} \mathrm{~cm} \mathrm{~m}^{-2}$ at a cell voltage of $0.7 \mathrm{~V}$.
\end{abstract}

Key Words : Perovskite-Type Oxide, Oxygen Reduction, Metal-Air Battery

\section{1 緒 言}

酸素の電気化学的還元は, 各種工業電解, 燃料電池や金属一 筀気電池のカソード反応として重要であり，これまでにもが ス拡散型電極などを用いて種々検討されている。高性能酸素 還元電極が得られれば, 省電力型食塩電解 ${ }^{1-3)}$ に適用できるだ けでなく，酸素陰極を組み合わせた各種電池の大幅な性能改 善につながる，例えば，軽量で高エネルギー密度という特徎 を有する金属一空気電池については，現在亜鉛一空気電池が ポケットベルや補聴器などの低出力用途向けの電源として用 いられているが, 電気自動車用など大型高出力電源への展開 も可能4)なろう。ただし，このような電極が実用化されるた めには, 単に高出力であるばかりでなく, 高温, 濃アルカリ 水溶液中での長期安定性に優れ，かつ低コストでなくてはな らない.これらの要件を満たすには電極材料とくに電極触媒 の選択が最も重要であり，これまでの研究も電極触媒に関す るものが最も多い。これまでに，電極触媒として高価な白金
などの貴金属やその合金 ${ }^{9-11)}$ 用いたがス拡散型電極が優れ た酸素還元特性を示すことが報告されているが，まだコスト 的に問題がある。これに対し，ある種のぺロブスカイト型酸 化物 ${ }^{5-8)}$ は, 安価で活性も比較的高い電極触媒材料として古く から注目され検討がなされているが，まだ性能的に充分満足 できるまでには到っていない。

著者らは，これまでペロブスカイト型酸化物(一般式 $\left.\mathrm{ABO}_{3}\right)$ のうち, $\mathrm{A}$ サイトにランタノイド元素, Bサイトに 遷移金属を含む一連の酸化物について, $\mathrm{A}, \mathrm{B}$ サイト金属の種 類や部分置換が電極触媒にどのような影響を与えるかを調べ てきな ${ }^{12-21)}$ そそれらの結果を要約すれば次のようになる。

（1）Bサイト金属が活性や安定性を最も大きく左右する。

(2) $\mathrm{Co}$ 系酸化物 $\left(\mathrm{ACoO}_{3}\right)$ は, 活性は最も高いが高温, 濃 アルカリでは安定でない.

(3) $\mathrm{Mn}$ 系酸化物 $\left(\mathrm{AMnO}_{3}\right)$ は, 安定性が高く, 活性も比較 的高い16). これらの酸化物の活性は, イオン半径が大きい $\mathrm{A}$ 
サイト金属（La，Pr， Nd）の場合に高くなる ${ }^{18)}$.

(4)この A サイトを 2 洒のアルカリ土類金属で部分置換す るとさらに電極活性が向上する ${ }^{19,20)}$.

ところでぺブスカイト型酸化物において，A サイトのラ ンタノイド元素 (3価) を低原子価金属で部分置換すれば，電 荷補償のために B サイトイオンの価数変化や酸素空孔の生 成が起こり，その結果，導電率や触媒活性の変化が生じるこ とが知られている ${ }^{22,23)}$. 上記(4)で述べた活性向上もこのよう な欠陥構造と関連するものと考えられる。このような観点か らは，A サイト置換元素を上記(4)のアルカリ土類金属 ( 2 価) からアルカリ金属（1洒）に変えたとき，活性がどのように 変化するか興味が持たれる．しかし，このようなアルカリ金 属を導入した系については，炭化水素の酸化触媒活性等に関 する報告 ${ }^{24-26)}$ があるだけで電極触媒活性に関する報告はな い.

そこで本研究では，A サイトにアルカリ金属を部分置換し た $\mathrm{Mn}$ 系ぺロブスカイト型酸化物, $\mathrm{La}_{1-x} \mathrm{~A}_{x} \mathrm{MnO}_{3}(\mathrm{~A}=$ $\mathrm{Na}, \mathrm{K}, \mathrm{Rb}, 0 \leqq x \leqq 0.2)$, を取り上げ, 酸素還元電極触媒と しての種々の性質を調べた，才なわち，一連の試料を用いた ガス拡散型酸素電極の分極特性から, 電極触媒活性とアルカ リ金属の種類や置換量との相関を明らかにするとともに，そ の反応機構を，回転リング・ディスク電極（rotating-ring disk electrode; RRDE）法や過酸化水素の分解活性の測定 結果を用いて検討した。また，酸化物上の酸素還元活性サイ トを推定するために，酸素の昇温脱離実騃，電子スピン共鳴 分析，及びヨードメトリによる Mn 価数の決定を行った。さ らに，得られたガス拡散型酸素電極の活性の安定性を調べる とともに，两鉛一空気電池を試作して，その出力特性を検討 した.

\section{2 実験方法}

\section{1 酸化物の調製}

$\mathrm{La}_{1-x} \mathrm{~A}_{x} \mathrm{MnO}_{3}(\mathrm{~A}=\mathrm{Na}, \mathrm{K}, \mathrm{Rb})$ はアモルファスリンゴ 酸前駆体 (amorphous malate precursor; AMP) 法 ${ }^{27)}$ より調製した。すなうち，所定モル比組成の金属硝酸塩とり ンゴ酸の混合水溶液をアンモ二ア水で $\mathrm{pH} 1.0$ に調整後, 約 $350^{\circ} \mathrm{C}$ で蒸発乾固, 熱分解を行い, $650-850^{\circ} \mathrm{C}$ で 5 時間, 空気 中で焼成することにより調製した，得られた各試料について は，粉末 X 線回折分析 (理学電機製 RINT 2100)により生成 物の同定を行った，酸化物の此表面積は， $\mathrm{N}_{2}$ 吸着による BET 法 (Quantachrome 社製 NOVA 1200) に上り求め た.

\section{2 ガス拡散型酸素電極の作製と分極特性の評価}

ガス拡散型酸素電極（Fig. I (a)）は，ガス供給層（厚さ： $0.25 \mathrm{~mm}$ ) と反応層（厚さ：0.15 mm）加成る二層構造と した。がス供給層は反応ガスの拡散がスムーズに進行し常に 反応層へガスを供給し続けると同時に電解液が外部に漏れる のを防ぐ構造であることが必要である。そのためには，多孔 質で踈水性が強いカーボンを用いることが望まれる。また， 反応層は導電パスを保ちつつ反応がス，電極触媒（あるいは カーボン) 及び電解液の三相界面を生成，維持する役割を担 う構造であることが必要である。そのためには，触媒を電極 中に高分散させるために高表面積のカーボンを使用するとと もに，このカーボンには電解液との接触を保ちつつも反応力゙ スの供給が常に進行する半疎水性の性質を持つことが望まれ
る. 本研究で用いた 2 種類のカーボンは上記の条件を満たす ものである ${ }^{16)}$. 実際には, ガス供給層としては疎水性が強いア セチレンブラック(電気化学工業製 $\mathrm{AB}-7$, 比表面積： $49 \mathrm{~m}^{2}$ ・ $\left.\mathrm{g}^{-1}\right)$ にポリテトラフルオロエチレン（ダイキン工業製 D-1, 以下 PTFEと略す)を $30 \mathrm{wt} \%$ 混合したものを，また反応層 としては半疎水性高表面積カーボンブラック（ケッチェンブ ラックインターナショナル製 EC $600 \mathrm{JD}$ ，比表面積：1270 $\left.\mathrm{m}^{2} \mathrm{~g}^{-1}\right)$ と PTFE (15 wt\%) の混合粉末にさらに酸化物触 媒(50 wt\%) )添加して混合したものを用いた。これらを $\mathrm{Ni}$ メッシュ集電体 (ニラコ製，100メッシュ) 上に順次積層した 後，ホットプレス（空気中， $370^{\circ} \mathrm{C}, 64 \mathrm{MPa}$ )することによ り電極を作製した，電極の分極特性は， $60^{\circ} \mathrm{C}, 8 \mathrm{~mol} \mathrm{dm}^{-3}$ $\mathrm{KOH}$ 水溶液中で電極毫面から空気を $100 \mathrm{~cm}^{3} \mathrm{~min}^{-1}$ で供 給しながら，ポテンシオスタット(北斗電工製 HA-303)を用 いて測定した，なお，対極には Pt 板，参照極には同液組成の $\mathrm{Hg} / \mathrm{HgO}$ 電極を用いた。 また，電極の長期安定性試験は，同 条件下で定電流密度 $\left(300 \mathrm{~mA} \mathrm{~cm}^{-2}\right)$ において行った。

亜鉛一空気電池は, 円筒形ポリビニル容器 (半径: 15 $\mathrm{mm}$, 高さ：20 mm）の底面側にガス拡散型酸素電極を貼り 付け，その上にセパレータ（ダイセル化学工業製，七ルガー ド 5511)，覀鈶粉末 (キシダ化学製，特級）を順次積層後，8 $\mathrm{mol} \mathrm{dm} \mathrm{dm}^{-3} \mathrm{KOH}$ 水溶液を注入し, 上方からアノード集電体

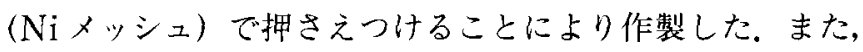
その出力特性はポテンシオスタットを用いて室温で測定した.

\section{3 酸素還元譏構の評価}

アルカリ水溶液中における酸素の電気化学的還元経路は, 一般に Fig. 2のように考えられている。すなわち，（I）のよ うな 4 電子還元により直接 $\mathrm{OH}^{-}$生ずる経路と，(II)の上 うに2 電子還元により $\mathrm{HO}_{2}{ }^{-を}$ を生じ，それが電気化学的還元 (a)あるいは接触分解(b)により $\mathrm{OH}^{-}$まで分解される経路であ る. $k_{1} \sim k_{4}$ は(1) 〜 (4)の各反応に対する速度定数であるが, これ らの評価には RRDE法が有効である。

RRDE 測定 ${ }^{13)}$ では, $25{ }^{\circ} \mathrm{C}, 1 \mathrm{~mol} \mathrm{dm}^{-3} \mathrm{KOH}$ 水溶液中

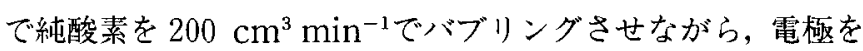
回転装置 (北斗電工製 HR-103 A) を用いて 400-2500 rpm で 回転させ, その時の分極特性を, 対極にPt らせん電極, 参照 極に同液組成の $\mathrm{Hg} / \mathrm{HgO}$ 電極を用いてデュアルポテンシオ スタット(北斗電工製 HR-103 B) により測定した。また，本 研究で用いたリング・ディスク電極は, Fig. 1(b)に示すよj にリングには金を使用し，銀製のディスク上のキャビティ（直 径：5 mm, 深さ：0.5 mm)に酸化物ペース卜を充填してぺ 一ストディスク電極とした。ペーストは，酸化物 (50 wt \%) とカーボン (キシダ化学製, 有機元素分析用カーボン) を混 合したものに少量の流動パラフィン（メルク製，特級）を加

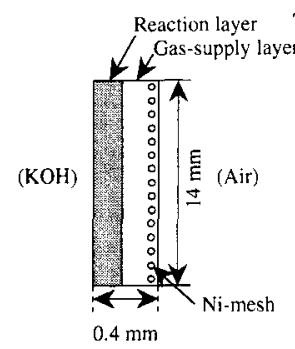

(a)

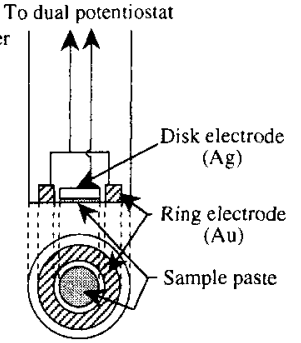

(b)
Fig. 1 Structure of gas diffusion-type oxygen electrode (a) and rotating ring-disk electrode (b). 


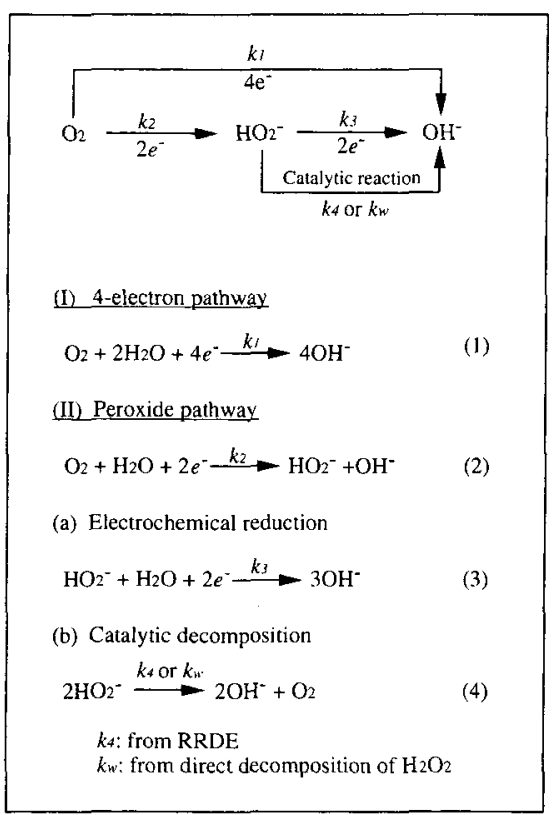

Fig. 2 Pathways of oxygen reduction in alkaline solution.

えてよく練り混ぜて調製した。ディスク電極は 0〜 -600 mV （vs： $\mathrm{Hg} / \mathrm{HgO}$ ）の範囲で酸素還元に対する分極特性を測定 した，一方，リング電極の電位は $+300 \mathrm{mV}$ に固定し，ディ スク電極上で酸素の 2 電子還元により生成した中間体である $\mathrm{HO}_{2}$-を検出した。これらの分極曲線を既報 ${ }^{13)}$ のうな計算 法を用いることにより，各速度定数を求めた。

$\mathrm{HO}_{2}{ }^{-}$の接触分解の反応速度定数 $k_{w}$ (RRDEでは $k_{4}$ に相 当) は, ガラス容器中の $8 \mathrm{~mol} \mathrm{dm}^{-3} \mathrm{KOH}$ 水溶液 $\left(40 \mathrm{~cm}^{3}\right)$ に酸化物試料を一定量 (10-50 g) 加之, $60^{\circ} \mathrm{C}$ に保った状態で $\mathrm{HO}_{2}$-水溶液 $(2 \mathrm{wt} \%) 5 \mathrm{~cm}^{3}$ を混合し, 反応(4)により生成す る酸素の発生量を直接测定することにより求めた。

酸化物のマンガン洒数及び酸素合量については，ヨードメ トリ法 ${ }^{201} に よ り$ 決定した。 また, 酸化物からの酸素の脱離挙動 は TPD 法 ${ }^{23)}$ により観察した。ささらに, ESR 分析 (日本電子 製，JES-FE1X）により，マンガンイオンから得られるスぺ クトル28,29にについても検討した。

\section{1 酸化物試料の同定}

\section{3 結果及び考察}

得られた酸化物 $\left(\mathrm{La}_{1-x} \mathrm{~A}_{x} \mathrm{MnO}_{3}, \mathrm{~A}=\mathrm{Na}, \mathrm{K}, \mathrm{Rb}\right)$ の粉 末 $\mathrm{X}$ 線回折分析の結果から，アルカリ金属で置換した試料 は, $x=0.2$ までは全てのピークが六方晶系のペロブスカイト 型酸化物である $\mathrm{LaMnO}_{3.15}$ (JCPDS No.32-484) に帰属で きることがわかった，本酸化物系では，ペロブスカイト型構 造形成能の指標として用いられるトレランスファクタ22)は適 正な範囲にあり，さらに 3.4 節で後述するTPD 曲線（Fig. 8)においても，アルカリ金属置換種や置換量を変化させるこ とにより無置換物 $\left(\mathrm{LaMnO}_{3}\right)$ とは明らかな相違が見られ た。よって，アルカリ金属イオンはぺロブスカイト格子中に

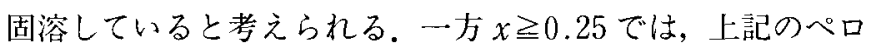
ブスカイト相とともに同定が不可能な不純物相のピークがみ られた.よって, $\mathrm{LaMnO}_{3}$ の $\mathrm{A}$ サイトへのアルカリ金属の固 溶限界は，約 $20 \mathrm{~mol} \%$ であると考えられる。

\section{2 ガス拡散型酸素電極の分極特性}

$\mathrm{LaMnO}_{3}$ の $\mathrm{A}$ サイトをアルカリ金属イオンで置換した試 料 $\left(\mathrm{La}_{0.8} \mathrm{~A}_{0.2} \mathrm{MnO}_{3}, \mathrm{~A}=\mathrm{Na}, \mathrm{K}, \mathrm{Rb}\right)$ を用いたガス拡散型 酸素電極の分極特性を，酸化物触媒を添加せずにカーボンだ けを用いて作彆したガス拡散型電極についての結果とともに Fig. 3 に示した. 酸化物を添加した電極はいずれも無添加の 電極よりもかなり高い活性を示しており,酸化物が酸素還元 触媒として有効に働いてることがわかる。 なかでもアルカリ 金属で部分置換した酸化物は, 無置換酸化物よりも優れた分 極特性を示す．電極活性の評価の指標として電位一 $150 \mathrm{mV}$ (vs. $\mathrm{Hg} / \mathrm{HgO})$ での電流密度 $\left(I_{150 \mathrm{mv}}\right)$ を用いると, 電極活 性は, $\mathrm{Rb}$ 部分置換で最も高く, $\mathrm{Rb}>\mathrm{K}>\mathrm{Na}>\mathrm{La}$ (無置換) の序列になる。

$\mathrm{Rb}$ 部分置換系について，置換量 $(x)$ 依存性をさらに検討 をした. Fig. 4 には, Rb 置換量 $(x)$ と電極活性 $\left(I_{150 \mathrm{~m}}\right)$ 及び酸化物の比表面積との相関を示す。活性は $x$ に大きく依 存し， $x=0.2$ で極大值をとるが，比表面積にはこのような顕 著な依存性は見られない。このことは，電極活性の $x$ 依存性 が酸化物表面の触媒活性の本質的な変化に由来することを示 している.なお， $x=0.25$ での電極性能の急激な低下は, $\mathrm{Rb}$ 置換限界を越えた組成となり不純物相が生成したためである と考えられる，そのため, 以下の実験や考察では $x=0.25 の$ 試料は除外した。

\section{3 酸化物触媒表面上での酸素還元反応経路}

上述した A サイト部分置換による活性変化の由来を検討

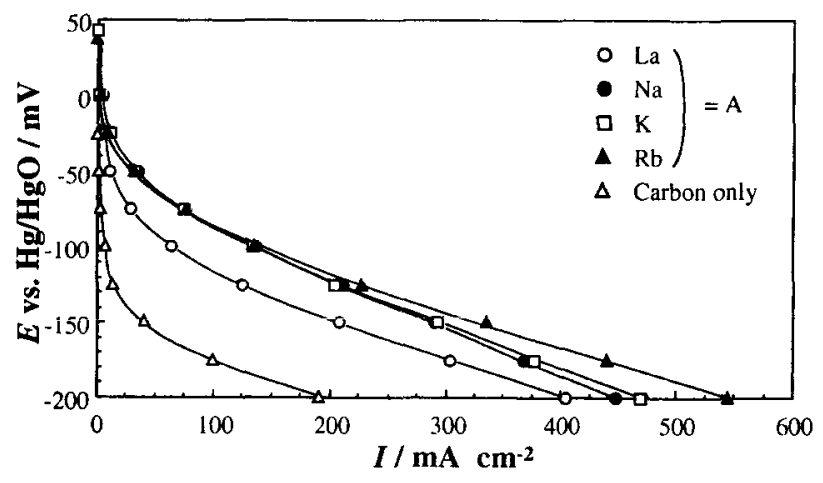

Fig. 3 Polarization curves of gas diffusion-type oxygen electrodes loaded with or without $\mathrm{La}_{0.8} \mathrm{~A}_{0.2} \mathrm{MnO}_{3}(50 \mathrm{wt} \%$ ) in $8 \mathrm{~mol} \mathrm{dm}^{-3} \mathrm{KOH}$ aqueous solution at $60^{\circ} \mathrm{C}$ under air flow $\left(100 \mathrm{~cm}^{3} \mathrm{~min}^{-1}\right)$.

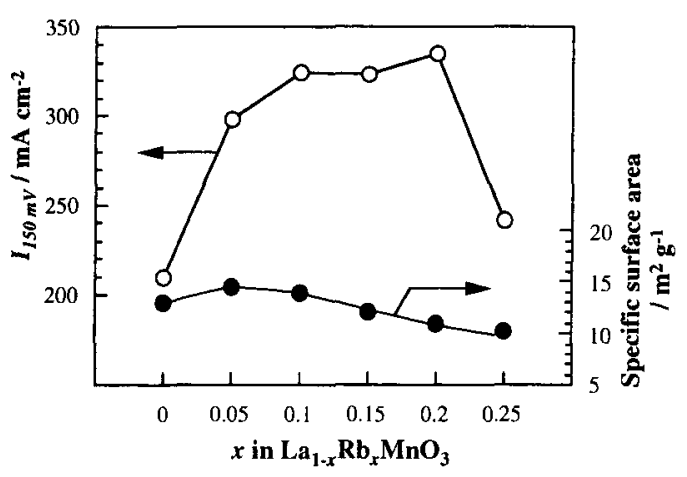

Fig. 4 Current density at $-150 \mathrm{mV}$ vs. $\mathrm{Hg} / \mathrm{HgO}\left(I_{150 \mathrm{mv}}\right)$ and specific surface area as a function of $x$ in $\mathrm{La}_{1-x} \mathrm{Rb}_{x}$ $\mathrm{MnO}_{3}$. 
するため, RRDE測定による反応経路の解析を行った. $\mathrm{La}_{0.8^{-}}$ $\mathrm{A}_{0.2} \mathrm{MnO}_{3}(\mathrm{~A}=\mathrm{La}, \mathrm{Na}, \mathrm{K}, \mathrm{Rb})$ 一カーボン混合ペースト を充填したディスク及びリング電極の回転数 $900 \mathrm{rpm}$ での 分極特性をカーボン単独ぺーストを充填した場合の結果とと もに Fig. 5 に示寸.カーボン単独電極では, ディスク電流值 $\left(I_{D}\right)$ が小さいのに対しリング電流值 $\left(I_{R}\right)$ はかなり大きく, 中間体である $\mathrm{HO}_{2}{ }^{-}$が大量に生成していることがわかる。一 方，酸化物混合電極では， $I_{D}$ はカーボン単独の場合よりも大 き増加するのに対し， $I_{R}$ は逆に大きく減少しており，酸素 の 4 電子還元が優先的に起こっていることがわかる.酸化物 混合電極では，部分置換元素の種類による影響が大きく，電 極電位 $-600 \mathrm{mV}$ (vs. $\mathrm{Hg} / \mathrm{HgO}$ ) で比較すると, $I_{D}, I_{R}$ と もにFig. 3 の場合と同様， $\mathrm{Rb}>\mathrm{K}>\mathrm{Na}>\mathrm{La}$ (無置換)の序 列となる. 同様の測定を他の回転数でも行い, 既報 ${ }^{13)}$ の方法に よって各還元経路の速度定数 $k_{1}, k_{2}, k_{3}+k_{4}$ を算出した。 そ の結果を Aサイト金属をパラメータとして Fig. 6 に示子。

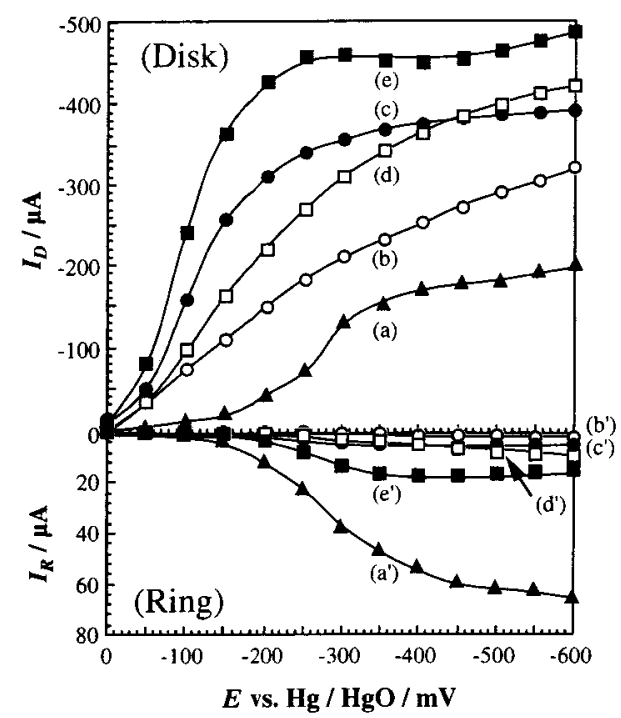

Fig. 5 Ring-disk currents $\left(I_{R}\right.$ and $\left.I_{D}\right)$ at $900 \mathrm{rpm}$ in $1 \mathrm{~mol}$. $\mathrm{dm}^{-3} \mathrm{KOH}$ aqueous solution at $25^{\circ} \mathrm{C}$ under pure oxygen flow. (a), (a') : Carbon only, (b), (b') : $\mathrm{LaMnO}_{3},(\mathrm{c}),\left(c^{\prime}\right): \mathrm{La}_{0.8}$ $\mathrm{Na}_{0.2} \mathrm{MnO}_{3}$, (d), (d') : $\mathrm{La}_{0.8} \mathrm{~K}_{0.2} \mathrm{MnO}_{3}$, (e), (e') : $\mathrm{La}_{0.8} \mathrm{Rb}_{0.2^{-}}$$\mathrm{MnO}_{3}$.

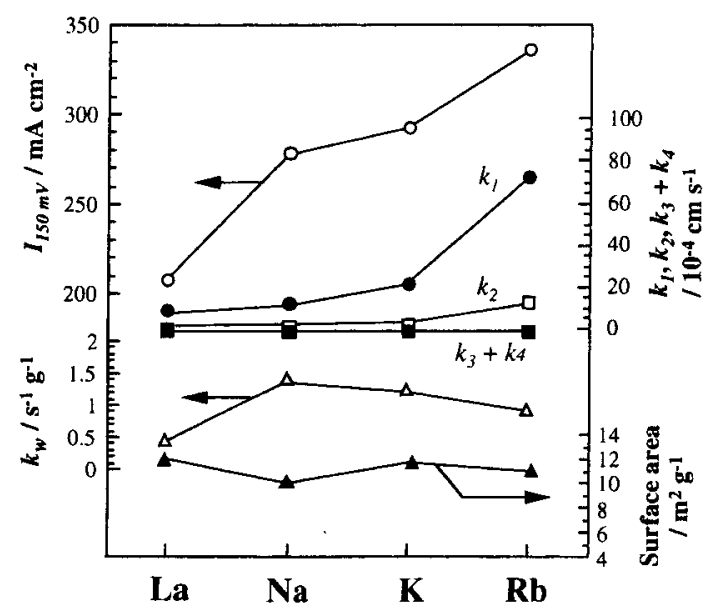

$\mathrm{A}$ in $\mathrm{La0.8A}_{0.2 \mathrm{MnO}}$

Fig. $6 I_{150 m v}, k_{1}, k_{2}, k_{3}+k_{4}, k_{w}$, and specific surface area as compared among $\mathrm{La}_{0.8} \mathrm{~A}_{0.2} \mathrm{MnO}_{3}$ oxides different in $\mathrm{A}$.
図では，前節で得られた電極活性 $\left(I_{150 \mathrm{mV}}\right)$, 酸化物の比表面 積及び別途测定して得た $\mathrm{HO}_{2}{ }^{-}$の接触分解速度定数 $\left(k_{w}\right)$ も あわせて示した，速度定数を比較すると，いずれの酸化物で も $k_{1}$ が $k_{2}$ 上りもかなり大きく，また $k_{3}+k_{4}$ はほぼゼロであ る.このことは 4 電子還元経路が支配的であることを示す。 また, $k_{1}$ の $\mathrm{A}$ サイト依存性が $I_{150} \mathrm{~m}_{V}$ のそれとほぼ対応した関 係にあることも，これを支持している．さらに $k_{w}$ の值（約 1 $\left.\mathrm{s}^{-1} \mathrm{~g}^{-1}\right)$ も以前報告した $\mathrm{La}_{0.6} \mathrm{Ca}_{0.4} \mathrm{CoO}_{3}$ の值 $\left(8-16 \mathrm{~s}^{-1}\right.$. $\left.\mathrm{g}^{-1}\right)^{15)}$ 約 $1 / 10$ であり，これは $k_{3}+k_{4}$ がほぼゼロであるこ とと合致している.

$\mathrm{Rb}$ 置換系についても同様の测定を行い，置換量 $x$ との相 関を調べな結果を Fig. 7 に示す。この場合でも $I_{150 \mathrm{mV}}$ は $k_{1}$ と類似した置換量依存性を示すが, $k_{3}+k_{4}$ や $k_{w}$ は置換量にほ とんど依存性しない，以前に我々は，Ca で部分置換した $\mathrm{Mn}$ 系ペロブスカイト型酸化物では, 置換量の増加とともに $k_{w}$ が 増大寸ることを見出し，それが活性サイトとしての酸化物上 の $\mathrm{Mn}^{4+}$ イオン濃度の增大によるものであると推定した ${ }^{20)}$. アルカリ金属置換した酸化物系ではこのような傾向は見られ ず，アルカリ土類金属置換系とは異なった経路で $\mathrm{HO}_{2}-$ の接 触分解反応が進むことを示唆している。

\section{4 酸化物触媒表面上の酸素還元活性サイト}

活性サイトに関する知見を得るために，酸化物からの酸素 の脱離挙動を TPD 法により調べた. $\mathrm{La}_{0.8} \mathrm{~A}_{0.2} \mathrm{MnO}_{3}(\mathrm{~A}=$ $\mathrm{La}, \mathrm{Na}, \mathrm{K}, \mathrm{Rb})$ 及び $\mathrm{La}_{1-x} \mathrm{Rb}_{x} \mathrm{MnO}_{3}(0 \leqq x \leqq 0.2)$ で得 られた結果をFig. 8(a)，(b)にそれぞれ示す.Fig. 8(a)からわ かるように，アルカリ金属の置換によって酸素の脱離ピーク 強度は無置換試料 $\left(\mathrm{LaMnO}_{3}\right)$ 上りも大幅に減少し, ピーク

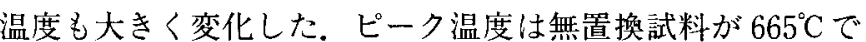
あるのに対して, $\mathrm{Na}, \mathrm{K}$ 置換試料ではそれぞれ $464^{\circ} \mathrm{C}, 756^{\circ} \mathrm{C}$ であり， Rb 置換試料では明確な脱離ピークは見られなかっ たが $680^{\circ} \mathrm{C}$ からほぼ一定の酸素脱離が見られた。 以前に我々 は，アルカリ土類金属を置換した Mn 系ペロブスカイト型酸 化物について，置換元素によって酸素脱離挙動に大きな違い

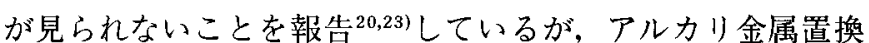
系では上述したように $\mathrm{Na}$ 置換系においてピークが低温側 へ大幅にシフトするなどの特徵的な挙動が観察された。一方， Fig. 8 (b)に示した Rb 置換量 $(x)$ を変化させた試料について は， $x$ の増加に伴い酸素脱離量は大幅に減少する傾向を示し た。この挙動は, 寺岡ら ${ }^{23)}$ が報告した $\mathrm{La}_{1-x} \mathrm{Sr}_{x} \mathrm{MnO}_{3}(0.0 \leqq$

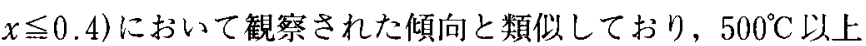
でのこのような高温での酸素脱離は酸化物格子中の $\mathrm{Mn}^{4+の}$ $\mathrm{Mn}^{3+}$ の還元に起因するものと思われる.ところで, $\mathrm{Mn}$

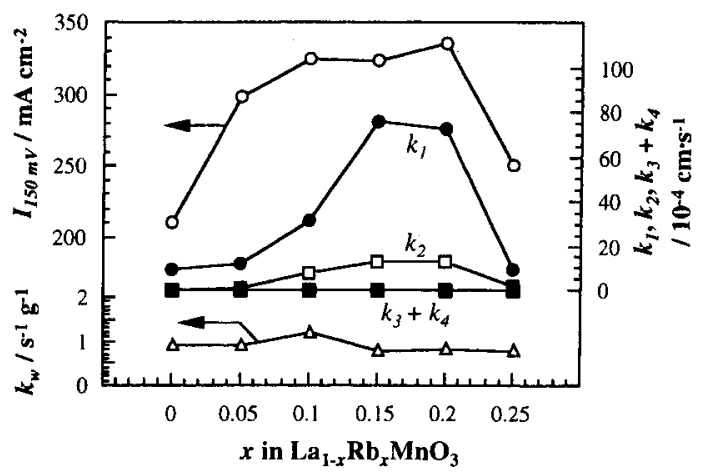

Fig. $7 I_{150 m v}, k_{1}, k_{2}, k_{3}+k_{4}, k_{w}$, and specific surface area as a function of $x$ in $\mathrm{La}_{1-x} \mathrm{Rb}_{x} \mathrm{MnO}_{3}$. 
(a) $\mathrm{La}_{0.8} \mathrm{~A}_{0.2} \mathrm{MnO}_{3}(\mathrm{~A}=\mathrm{La}, \mathrm{Na}, \mathrm{K}, \mathrm{Rb})$

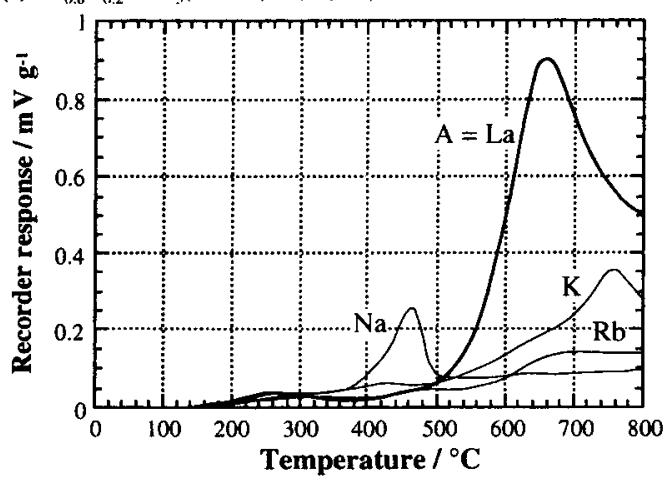

(b) $\mathrm{La}_{1-x} \mathrm{Rb}_{x} \mathrm{MnO}_{3}(0.0 \leq x \leq 0.2)$

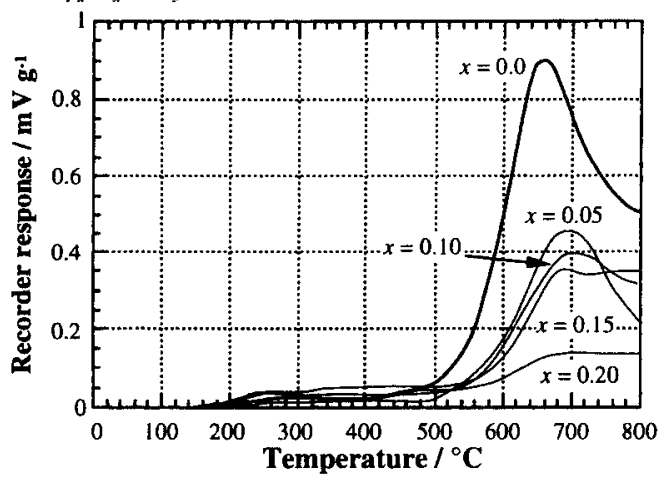

Fig. 8 TPD chromatograms of oxygen from $\mathrm{La}_{0.8} \mathrm{~A}_{0.2^{-}}$ $\mathrm{MnO}_{3}$ (a) and $\mathrm{La}_{1-x} \mathrm{Rb}_{x} \mathrm{MnO}_{3}$ (b).

(IV) $\mathrm{O}_{2}$ の $\mathrm{Mn}$ (III) ${ }_{2} \mathrm{O}_{3}$ への熱分解温度が $535^{\circ} \mathrm{C}$ であることか ら考えると，この温度よりピーク温度が高い $\mathrm{A}=\mathrm{La}$ （無置 換), $\mathrm{K}, \mathrm{Rb}$ 試料では, 格子中の $\mathrm{Mn}^{4+}$ がペロブスカイト格子 に収容されることで安定化されるのに対して，脱離ピークが 低温側へ唯一シフトした Na 置換試料のみが格子中の $\mathrm{Mn}^{4+}$ が不安定化されていると推察される。しかし， Na 置換試料で

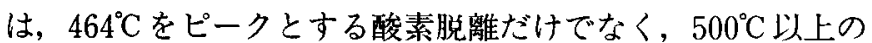
温度域においても酸素脱離が引き続いて起こっていることか ら, 安定化された $\mathrm{Mn}^{4+}$ 混在しているものと考えられる.以 上のような TPD 测定から得られた結果から, $\mathrm{Mn}^{4+}$ から $\mathrm{Mn}^{3+}$ への還元に伴う酸素脱離量を算出する場合には, $\mathrm{Na}$ 置 換試料では $400^{\circ} \mathrm{C}$ 以上,他の試料では $500^{\circ} \mathrm{C}$ 以上での酸素脱離 を取り报う必要があると考えられる，Fig. 9(a)，(b)には，両 酸化物系試料についてアルカリ金属置換種あるいは $\mathrm{Rb}$ 置換 量に対する電極活性 $\left(I_{150 \mathrm{mV}}\right)$ 及び酸素脱離量 $\left(\mathrm{Mn}^{4+}\right.$ から $\mathrm{Mn}^{3+へ の}$ 還元量に対応) との相関を示す.これらの図より， 酸素脱離量が減少するほど，才なわち酸化物中の $\mathrm{Mn}^{4+}$ が安 定化されるほど電極性能は向上することがわかる．この傾向 は両試料系において同様に見られるため，アルカリ金属を置 換した Mn 系ペロブスカイト型酸化物では格子中に安定に 存在する $\mathrm{Mn}^{4+}$ が酸素還元に重要な役割を果たしていると思 われる。

そこで，ヨードメトリによって $\mathrm{La}_{1-x} \mathrm{Rb}_{x} \mathrm{MnO}_{3} \quad(0 \leqq x \leqq$ $0.2)$ 試料中の $\mathrm{Mn}^{4+}$ 存在量を求めた. Fig. 10 に, ヨード メトリから求めた酸化物中の $\mathrm{Mn}^{3+}, \mathrm{Mn}^{4+}$ 量, 及び酸素含量 $(3+\delta)$ と $\mathrm{Rb}$ 置換量との相関を示す。なお，マンガン価数の 決定は, 酸化物中に $\mathrm{Mn}^{3+}$ と $\mathrm{Mn}^{4+}$ のみが存在するものとし て計算した。この図より,酸素含量は $\mathrm{Rb}$ 置換量の増加ととも にほぼ単調に減少するが, $\mathrm{Mn}^{3+}, \mathrm{Mn}^{4+}$ 量はほぼ一定である

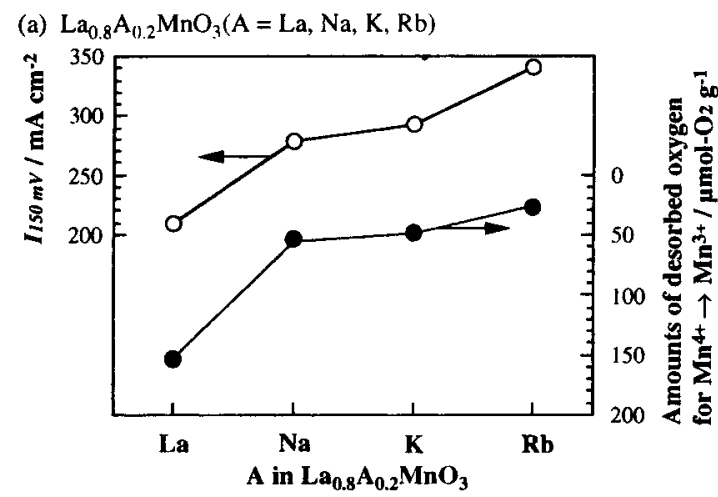

(b) $\mathrm{La}_{1 \cdot x} \mathrm{Rb}_{x} \mathrm{MnO}_{3}(0.0 \leq x \leq 0.2)$

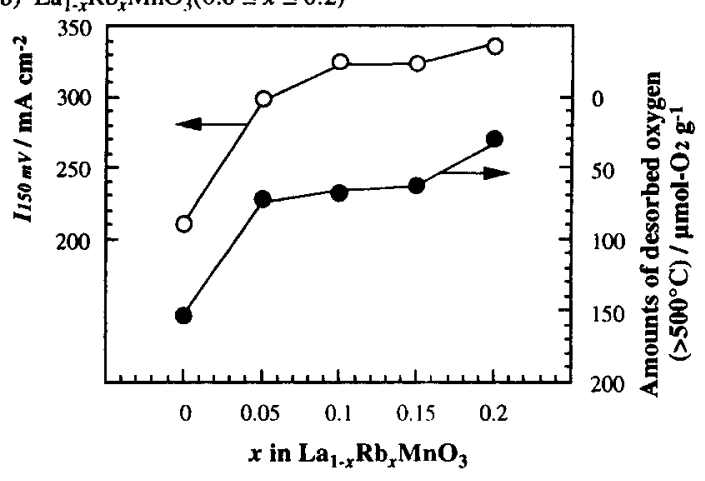

Fig. 9 Parallelism between $I_{150 \mathrm{mv}}$ and the amount of desorbed oxygen for a series of $\mathrm{La}_{0.8} \mathrm{~A}_{0.2} \mathrm{MnO}_{3}$ oxides (a) or $\mathrm{La}_{1-x} \mathrm{Rb}_{x} \mathrm{MnO}_{3}$ oxides (b).

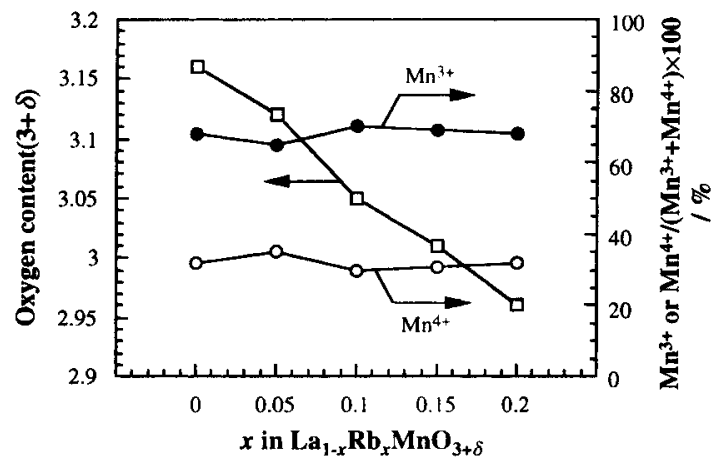

Fig. 10 Oxygen content $(3+\delta)$, and relative distributions of $\mathrm{Mn}$ between $\mathrm{Mn}^{3+}$ and $\mathrm{Mn}^{4+}(\%)$ as a function of $x$ in $\mathrm{La}_{1-x} \mathrm{Rb}_{x} \mathrm{MnO}_{3}$.

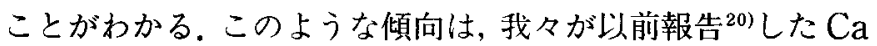
置換量の増加とともに $\mathrm{Mn}^{4+}$ 量がほほ単調に増加する Pr$\mathrm{Ca}-\mathrm{Mn}-\mathrm{O}$ 系についての傾向とは異なる.したがって, 本酸化 物系のアルカリ金属置換にともなう電気的中性条件の補償は 主に酸素含量の減少によって満たされているものと考えられ る.ところで, Pr-Ca-Mn-O 系においては $\mathrm{HO}_{2}$-の接触分解

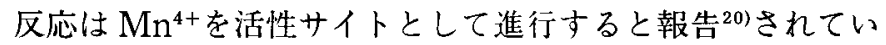
る。しかし, 本試料系においては $\mathrm{Mn}^{4+}$ 量がほぼ一定であるた めに, 前述したように $k_{w}$ も $\mathrm{Rb}$ 置換量にほとんど依存しない と考えられる。

以上のように，予想に反して $\mathrm{Mn}^{4+}$ 量と電極性能との問に は良好な相関は見られなかった。そこで，酸化物中での $\mathrm{Mn}$ イオンの存在状態についての知見を得るために, $\mathrm{La}_{1-x} \mathrm{Rb}_{x^{-}}$ $\mathrm{MnO}_{3}$ 系試料について ESR 測定を行った. Fig. 11 に, 得ら 


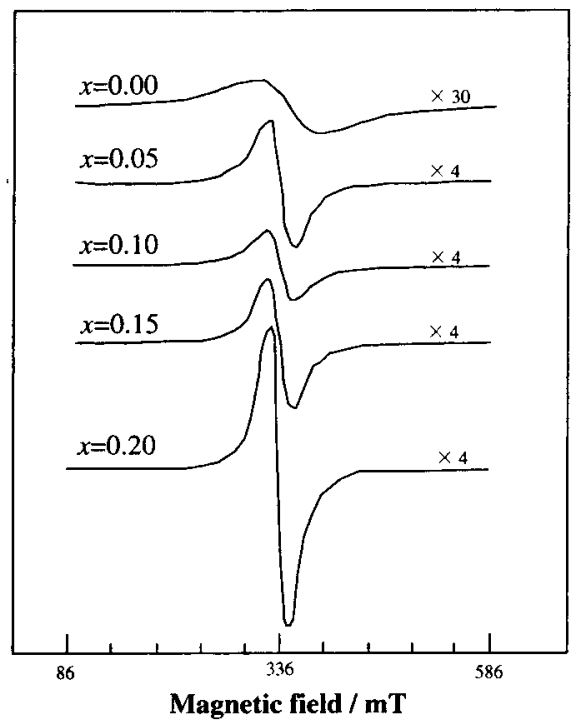

Fig. 11 ESR spectra of $\mathrm{La}_{1-x} \mathrm{Rb}_{x} \mathrm{MnO}_{3}$ oxides $(0 \leqq x \leqq 0.2)$.

れた ESR スペクトルを示す。これより，スペクトルは Rb 置 換量が増加するにつれて大きくかつ鋭くなることがわかる。 このスペクトルは, $\mathrm{Mn}^{3+}$ と $\mathrm{Mn}^{4+}$ が酸素イオンを介して隣り 合うことにより起こる電子の 2 重交換相互作用 ${ }^{30}$ によるもの であると考えられている. $x=0.2$ でスぺクトルが最も強くな るという傾向は, 電極性能の傾向と一致しているため, $\mathrm{Mn}^{3+}$ と $\mathrm{Mn}^{4+}$ が隣接するサイトで酸素の 4 電子還元反応が促進さ れていると考えられる。このような隣接サイトの数は, $\mathrm{Mn}^{3+}$ と $\mathrm{Mn}^{4+}$ 分率がそれぞれ $50 \%$ の時に最大となると考えら れるが, 本酸化物系ではヨードメトリの結果より，この分率 にほとんど変化がないことが確認されている。よってここで 観察された ESR スペクトル強度の Rb 置換量に伴う增加は, 無置換試料（ $\mathrm{La}_{1-\alpha} \square_{\alpha} \mathrm{Mn}_{1-\beta} \square_{\beta} \mathrm{O}_{3} ）$ に存在するカチオン空 孔（口）が $\mathrm{Rb}$ 置換によって消滅して定比組成に近づくため に，兩マンガンイオンが隣接する確立が高くなったために生 じたと考えられる。しかし，スペクトル強度が小さい無置換 $\left(\mathrm{LaMnO}_{3}\right)$ 試料でもカーボン単独電極よりも高い電極性能 を有することから, $\mathrm{Mn}^{3+} ま な は \mathrm{Mn}^{4+}$ だけでも活性サイトと して作用していると考えられる。

以上得られた知見を基にすると，酸素還元反応に対する本 酸化物系の触媒作用については, 酸化物表面の $\mathrm{Mn}^{3+}$ 及び $\mathrm{Mn}^{4+}$ がそれぞれ活性サイトとして単独でも作用するが，そ のうち $\mathrm{Mn}^{3+}$ と $\mathrm{A}$ サイト置換により安定化された $\mathrm{Mn}^{4+}$ が 酸素イオンを介して隣接することにより活性がさらに增大し ているものと考察される.また,アルカリ金属の中でも $\mathrm{Rb}$ 置 換系が最も高い活性を示すのは，格子中で $\mathrm{Mn}^{4+}$ が最も安定 化されており $\mathrm{Mn}^{3+}$ との隣接による 4 電子還元活性の促進効 果が他の置換系よりも顕著に現れたためであると考えられる。

\section{5 ガス拡散型酸素電極の長期安定性と亜鉛一空気電池へ}

\section{の応用}

本研究で検討した酸化物試料のうち最も高い活性を示した $\mathrm{La}_{0.8} \mathrm{Rb}_{0.2} \mathrm{MnO}_{3}$ と以前報告した $\mathrm{La}_{0.6} \mathrm{Ca}_{0.4} \mathrm{CoO}_{3}{ }^{16)}$ をれれ゙ れ用いてガス拡散型酸素電極を作製し，これらについて高電 流密度下 $\left(300 \mathrm{~mA} \mathrm{~cm}^{-2}\right)$ での耐久試験を行った。 その結果 を Fig. 12 に示亦が, $\mathrm{La}_{0.6} \mathrm{Ca}_{0.4} \mathrm{CoO}_{3}$ を用いた電極は，初期 活性は高いものの 100 時間後には約 $100 \mathrm{mV}$ の過電圧増加 が見られた。一方， $\mathrm{La}_{0.8} \mathrm{Rb}_{0.2} \mathrm{MnO}_{3}$ を用いた電極は多少の電
位の変化がみられたが, 測定を行った 100 時間，ほぼ安定に 作動することがわかった．酎久試騃前後に各電極の XRD 測 定を行い, 酸化物の構造の安定性について調べた. Fig. 13 に 示すように, $\mathrm{La}_{0.6} \mathrm{Ca}_{0.4} \mathrm{CoO}_{3}$ は試験後に水酸化ランタンの生 成が見られると同時に，ペロブスカイト相のピークが大きく 減少していた. 一方, $\mathrm{La}_{0.8} \mathrm{Rb}_{0.2} \mathrm{MnO}_{3}$ では, 若干の水酸化ラ ンタンの生成が認められたが, ベロブスカイト相のピーク強 度は耐久試験前とほほ同程度を小しており, $\mathrm{La}_{0.6} \mathrm{Ca}_{0.4} \mathrm{CoO}_{3}$ よりも高い安定性を有していることがわかった。したがって， この $\mathrm{La}_{0.8} \mathrm{Rb}_{0.2} \mathrm{MnO}_{3}$ は, カソード還元分極下, 高温, 濃アル カリ水溶液中, 高電流密度という厳しい条件下でも使用が可 能な電極触媒として有望であると思われる。

$\mathrm{La}_{0.8} \mathrm{Rb}_{0.2} \mathrm{MnO}_{3}$ を用いたガス拡散型酸素電極及び亜鉛粉 末をそれぞれカソード，アノードとして亜鉛一空気電池を実 際に作製し，その電池特性について検討した，比較のために， $\mathrm{Pt}$ 触媒をコロイド吸着法でカーボンに担持 $(0.56 \mathrm{mg}-\mathrm{Pt}$ $\mathrm{cm}^{-2}$ )したがス拡散型酸素電極老用いた亜鈆一空気電池もあ わせて測定を行った. Fig. 14 に, 電池の分極特性及び出力特 性を示す。セル電压 $1.0 \mathrm{~V}$ の時, $\mathrm{La}_{0.8} \mathrm{Rb}_{0.2} \mathrm{MnO}_{3}$ 触媒を用い たセル(a)の電流密度は $202 \mathrm{~mA} \mathrm{~cm}^{-2}$ を示し, $\mathrm{Pt}$ 触媒を用い たセル(b)の)約 1.8 倍の性能を示した。また，七ル(a)の最高出

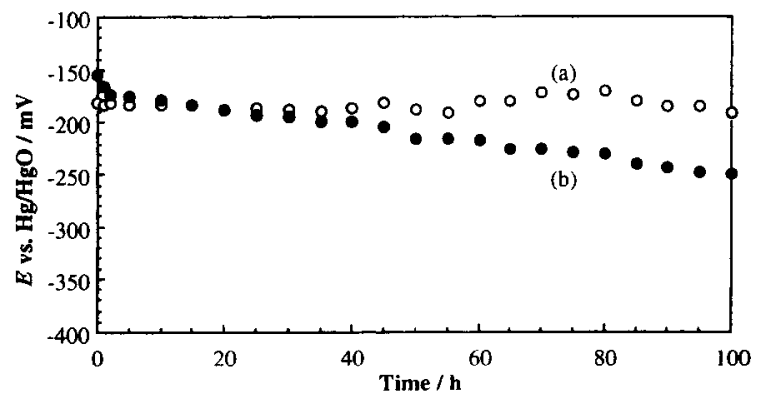

Fig. 12 Continuous oxygen-reduction tests over $100 \mathrm{~h}$ for gas diffusion-type oxygen electrodes loaded with $\mathrm{La}_{0.8} \mathrm{Rb}_{0.2}$. $\mathrm{MnO}_{3}(\mathrm{a})$ and $\mathrm{La}_{0.6} \mathrm{Ca}_{0.4} \mathrm{CoO}_{3}(\mathrm{~b})$ at a galvanostatic condition of $300 \mathrm{~mA} \mathrm{~cm}^{-2}$ in $8 \mathrm{~mol} \mathrm{dm}^{-3} \mathrm{KOH}$ aqueous solution at $60^{\circ} \mathrm{C}$ under air flow.

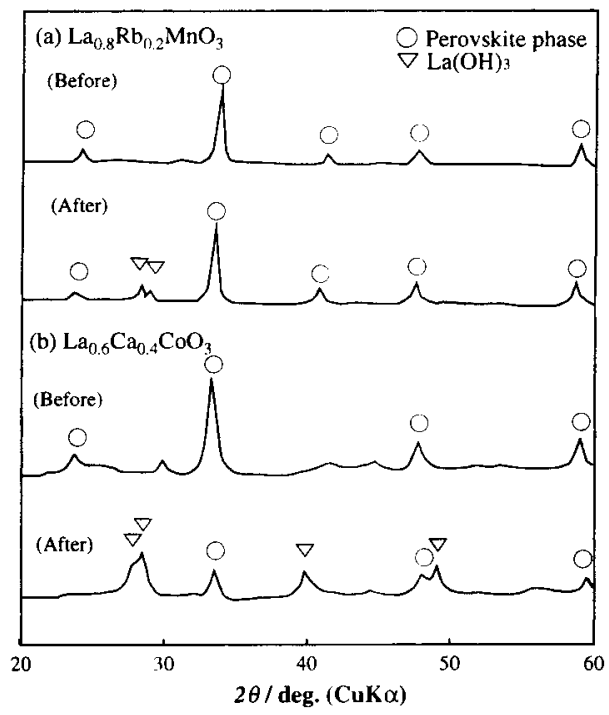

Fig. 13 XRD patterns of the oxide catalysts loaded in the electrodes before and after the continuous reduction tests. (a) $\mathrm{La}_{0.8} \mathrm{Rb}_{0.2} \mathrm{MnO}_{3}$ and (b) $\mathrm{La}_{0.6} \mathrm{Ca}_{0.4} \mathrm{CoO}_{3}$. 


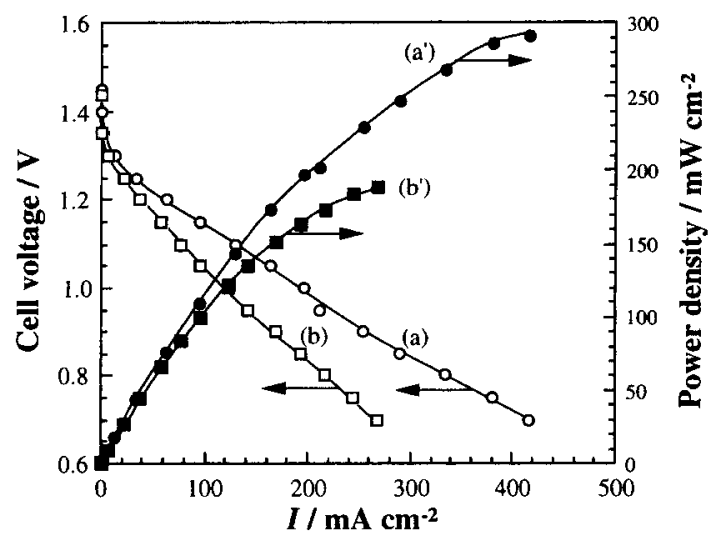

Fig. 14 Discharge characteristics of zinc-air batteries using gas diffusion-type oxygen electrodes loaded with $\mathrm{La}_{0.8} \mathrm{Rb}_{0.2} \mathrm{MnO}_{3}\left(50 \mathrm{wt} \%\right.$ ) (a) and Pt (0.56 mg cm$\left.{ }^{-2}\right)$ (b).

力密度もセル(b)の約 1.5 倍の $293 \mathrm{~mW} \mathrm{~cm}^{-2}$ を示した. 各電 極触媒のコストを大まかに見積もると, 本酸化物は $\mathrm{Pt}$ の約 1/30 程度と低いことがわかった. したがって，この $\mathrm{La}_{0.8}$ $\mathrm{Rb}_{0.2} \mathrm{MnO}_{3}$ は高活性かつ低コストな実用的触媒として有望 であると考えられる。

\section{4 結 論}

濃アルカリ水溶液用ガス拡散型酸素電極触媒として $\mathrm{La}_{1-x}$ $\mathrm{A}_{x} \mathrm{MnO}_{3}(\mathrm{~A}=\mathrm{Na}, \mathrm{K}, \mathrm{Rb}, 0 \leqq x \leqq 0.2)$ を取り上げて検討 した結果，次のような知見が得られた。

(1) 本酸化物系では, $\mathrm{Rb}$ 置換系が最も活性が高く, $x=0.2$ の 時に電極性能は極大值を示した。

(2) 酸化物上の反応は, 主に酸素の直接 4 電子還元経路によ って進行し, $\mathrm{Mn}^{3+}$ と安定に存在する $\mathrm{Mn}^{4+}$ が酸化物イオンを 介して隣接するサイトにおいて促進されることがわかった.

(3) $\mathrm{La}_{0.8} \mathrm{Rb}_{0.2} \mathrm{MnO}_{3}$ を用いたガス拡散型酸素電極は，高温， 濃アルカリ水溶液中, $300 \mathrm{~mA} \mathrm{~cm}^{-2}$ という高電流密度下でも 測定を行った 100 時間ほぼ安定に作動した。

(4) $\mathrm{La}_{0.8} \mathrm{Rb}_{0.2} \mathrm{MnO}_{3}$ を酸素電極触媒として用いた亜鉛一空 気電池は，Pt 触媒を用いた場合よりも高出力を示し, さらに より低いコストで作製が可能なことがわかった。

\section{文献}

1) E. Yeager, Soda \& Chlorine, 31, 147 (1980) (in Japanese).

2) T. Ashida, S. Wakita, and M. Tanaka, Denki Kagaku (presently Electrochemistry), 65, 1026 (1997).

3) A, Uchimura, O. Ichinose, and N. Furuya, Denki Kagaku (presently Electrochemistry), 65, 1032 (1997).

4) F. G. Will, Power Sources for Electric Vehicles, (Ed. B. D. McNichol), Elsevier, pp. 573 (1984).

5) Y. Matsumoto, H. Yoneyama, and H. Tamura, Chem. Lett., 661 (1975).
6) T. Kudo, H. Obayashi, and M. Yoshida, J. Electrochem. Soc., 124, 321 (1977).

7) K. L. K. Yeung and A. C. C. Tseung, J. Electrochem. Soc., 125, 878 (1978).

8) C. K. Lee, K. A. Striebel, F. R. McLarnon, and E. J. Cairns, J. Electrochem. Soc., 144, 3801 (1997).

9) M. Watanabe, M. Uchida, and S. Motoo, J. Electronal. Chem., 199, 311 (1986).

10) M. Watanabe, K. Tsurumi, T. Mizukami, T. Nakamura, and P. Stonehart, J. Electrochem. Soc., 141, 2659 (1994).

11) T. Toda, H. Igarashi, and M. Watanabe, J. Electrochem. Soc., 145, 4185 (1998).

12) Y. Shimizu, A. Nemoto, T. Hyodo, N. Miura, and N. Yamazoe, Denki Kagaku (presently Electrochemistry), 61, 1458 (1993).

13) N. Miura, Y. Shimizu, N. Yamazoe, and T. Seiyama, Nippon Kagaku Kaishi, 644 (1985) (in Japanese).

14) N. Miura, Y. Shimizu, and N. Yamazoe, Nippon Kagaku Kaishi, 751 (1986) (in Japanese).

15) Y. Shimizu, K. Uemura, H. Matsuda, N. Miura, and N. Yamazoe, J. Electrochem. Soc., 137, 3430 (1990).

16) T. Hyodo, Y. Shimizu, N. Miura, and N. Yamazoe, Denki Kagaku (presently Electrochemistry), 62, 158 (1994) (in Japanese).

17) T. Hyodo, N. Miura, and N. Yamazoe, Mat. Res. Soc. Symp. Proc., 393, 79 (1995).

18) T. Hyodo, M. Hayashi, N. Miura, and N. Yamazoe, $J$. Electrochem. Soc., 143, L266 (1996).

19) T. Hyodo, M. Hayashi, S. Mitsutake, N. Miura, and N. Yamazoe, J. Appl. Electrochem., 27, 745 (1997).

20) T. Hyodo, M. Hayashi, S. Mitsutake, N. Miura, and N. Yamazoe, J. Ceram. Soc. Japan, 105, 412 (1997) (in Japanese).

21) M. Hayashi, H. Uemura, K. Shimanoe, N. Miura, and N. Yamazoe, Electrochemical and Solid-State Letters, 1, 268 (1996).

22）日本化学会編, 季刊化学総説 32 , ペロブスカイト関連化合物 機能の宝庫, 学会出版センター pp. 58-62, 150-155 (1997).

23) H. M. Zhang, Y. Teraoka, and N. Yamazoe, J. Surf. Sci. Jpn., 8, 23 (1987) (in Japanese).

24) R. J. H. Voorhhoeve, J. P. Remeika, L. E. Trimble, A. S. Cooper, F. J. Disalvo, and P. K. Gallagher, J. Solid State Chem., 14, 395 (1975).

25) A. Shamsi and K. Zahir, Energy \& Fuels, 3, 727 (1989).

26) R. Hildrum, S. Aasland, and $\emptyset$. Joahannesen, Solid State Ionics, 66, 207 (1993).

27) Y. Teraoka, H. Kakebayashi, I. Moriguchi, and S. Kagawa, Chem. Lett., 673 (1991).

28) J. H. Choy, G. Demazeau, and S. T. Hong, Jpn. J. Appl. Phys., 31, 3649 (1992).

29) J. H. Choy, G. Demazeau, S. H. Byeon, and J. M. Dance, J. Phys. Chem. Solids, 51, 391 (1990).

30) C. Zener, Phys. Rev., 82, 403 (1951). 